European Journal of STEM Education, 2:1 (2017), 1

ISSN: $2468-4368$

\title{
Development Status of Higher Education in Northern Indian: A Review Study
}

\author{
Chaman Verma ${ }^{1}$
}

1 Jan Nayak Ch. Devi Lal Vidyapeeth, Sirsa, Haryana, INDIA

*Corresponding Author: chaman.verma@gmail.com

Citation: Verma, C. (2017) Development Status of Higher Education in Northern Indian: A Review Study , European Journal of STEM Education, 2:1 (2017), 1. doi: http://dx.doi.org/10.20897/ejsteme.201701

Published: April 30, 2017

\begin{abstract}
In development of any country depends upon higher educational status. India is fast growing country in the field of education and technology. Most of IT engineers are deputed in world's most IT companies. It has been possible because of strong development higher education system in India. This paper focuses on the comparative study of higher educational universities located in Haryana and Punjab. The findings of this paper explores that government has emphasized on privatization of higher education in two states.
\end{abstract}

Keywords: government, private, higher education, state

\section{INTRODUCTION}

Before November 1966, Haryana was the part of larger Punjab region. It was founded in 1st November 1966 which has 21 cities and population of Haryana is above 10 million. On the other hand Punjab has a population of more than 27 million and 22 districts. Haryana and Punjab are the two powerful and economy states of North India. The capital of both states is Chandigarh. The level of education is very high as compared two other states. Higher education includes many central universities, state universities and colleges, where students are pursuing graduation and post graduation as well as post doctorate courses. The concept of Private University development has introduced after the year 2000; it seems; as no private Universities have been developed in both states.

Table 1 describes the present scenario of University establishment in two states. There are total thirty three government and thirty private Universities available for Higher Education in both states. The total count of universities is thirty two and twenty one in Haryana and Punjab respectively. Fifteen years ago, there was no private University available in states.

Table 1 Government and Private Universities in Haryana and Punjab

\begin{tabular}{|c|c|c|c|c|c|}
\hline S.No. & State & Years & Government Universities & Private Universities & Total \\
\hline \multirow{2}{*}{1} & \multirow{2}{*}{ Haryana } & Before 2000 & 04 & 0 & \multirow[t]{2}{*}{32} \\
\hline & & After 2000 & 10 & 18 & \\
\hline \multirow{2}{*}{2} & \multirow{2}{*}{ Punjab } & Before 2000 & 04 & 0 & \multirow[t]{2}{*}{21} \\
\hline & & After 2000 & 05 & 12 & \\
\hline & Total & & 23 & 30 & 53 \\
\hline
\end{tabular}




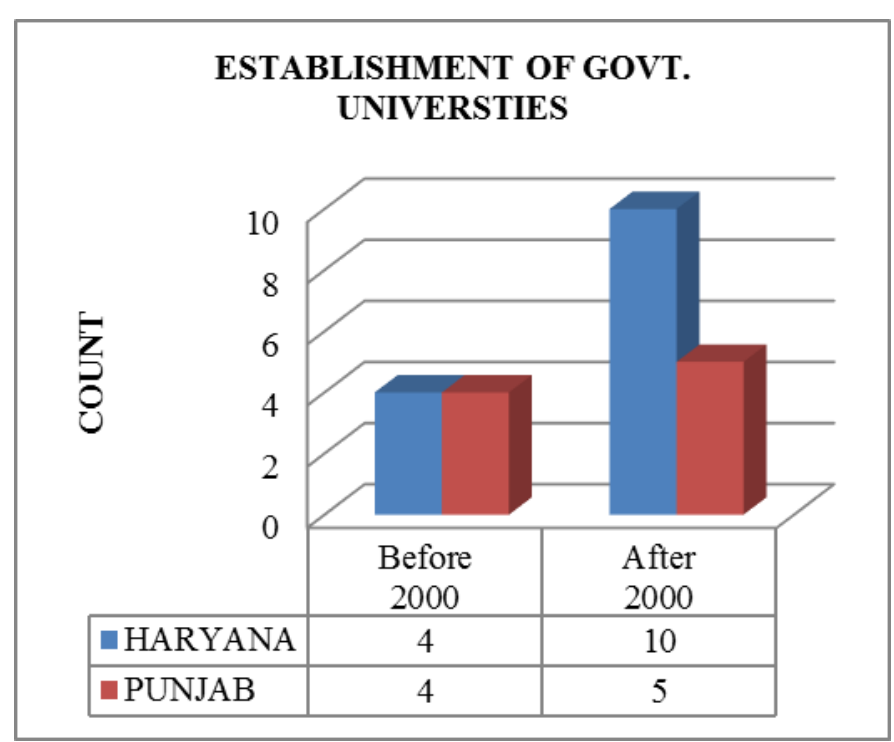

Figure 1. Government Universities in Haryana and Punjab

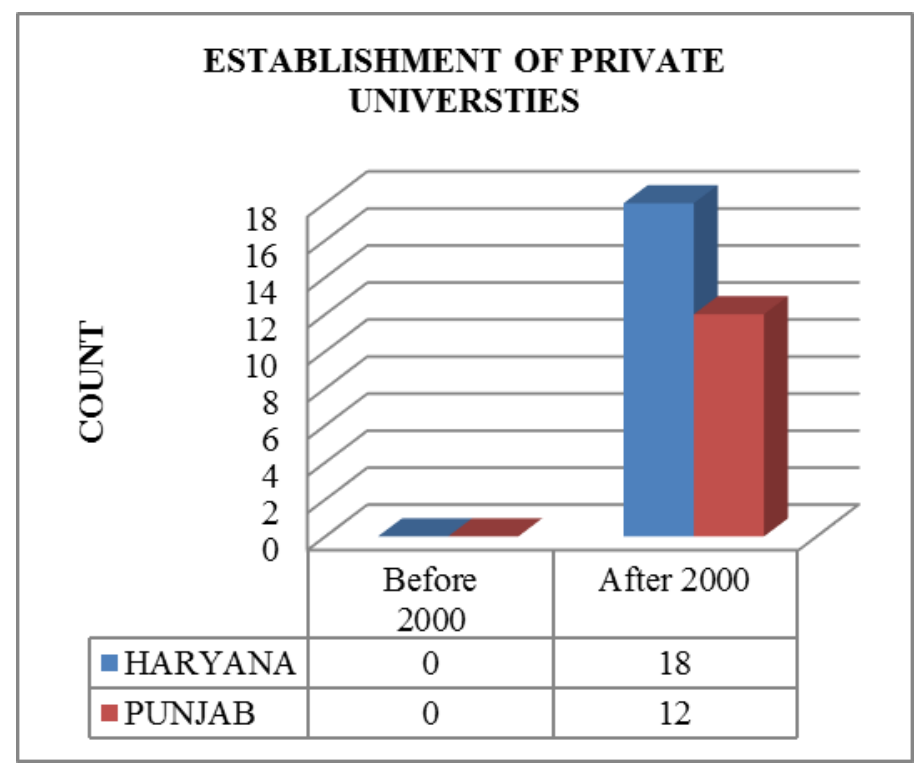

Figure 2. Private Universities in Haryana and Punjab

Figure 1 shows that before 2000 there was same count of government Universities establishment and Haryana state is leading Punjab as double count of Universities development which is showing rapid growth of Higher education in Haryana as compare to Punjab.

Figure 2 is stating that before 2000, the concept of Private Universities was not adapted by concerned states. But after 2000, eighteen and twelve private Universities have been established in Haryana and Punjab states respectively.

\section{UNIVERSITIES IN HARYANA}

University Grant Commission (UGC) has issued notification to declare various private Universities in Haryana state on 11 September 2015. Eighteen private Universities have been declared and enlisted. In the year 2014, four private Universities have been setup in NCR cities Faridabad, Gurgaon and Sonepat. Figure 3 is showing the name, city and year of establishment of private universities located in Haryana. The Punjab state is lags behind Haryana in private Universities development; as there were only twelve private Universities have been established. 


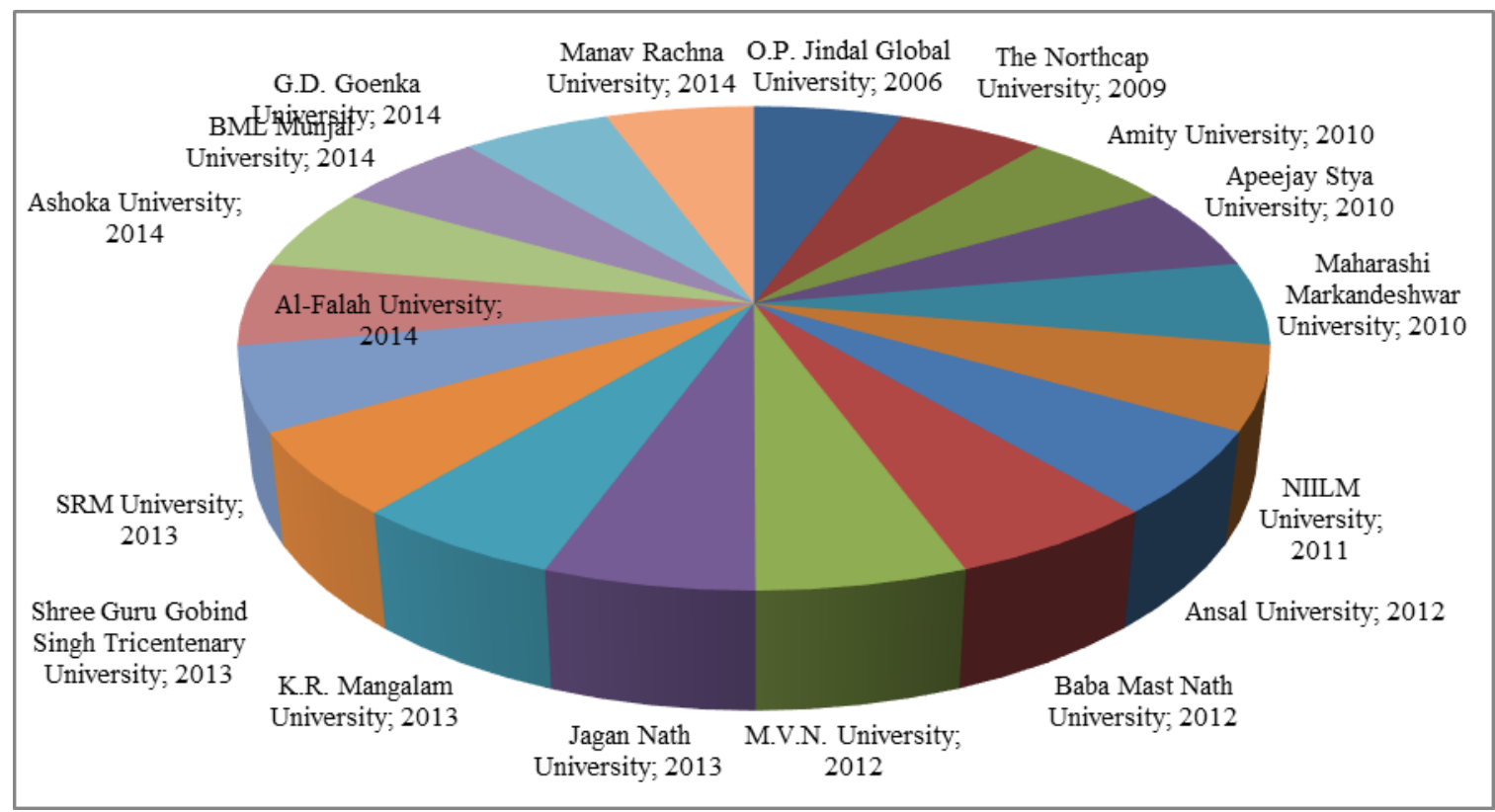

Figure 3. Private Universities in Haryana

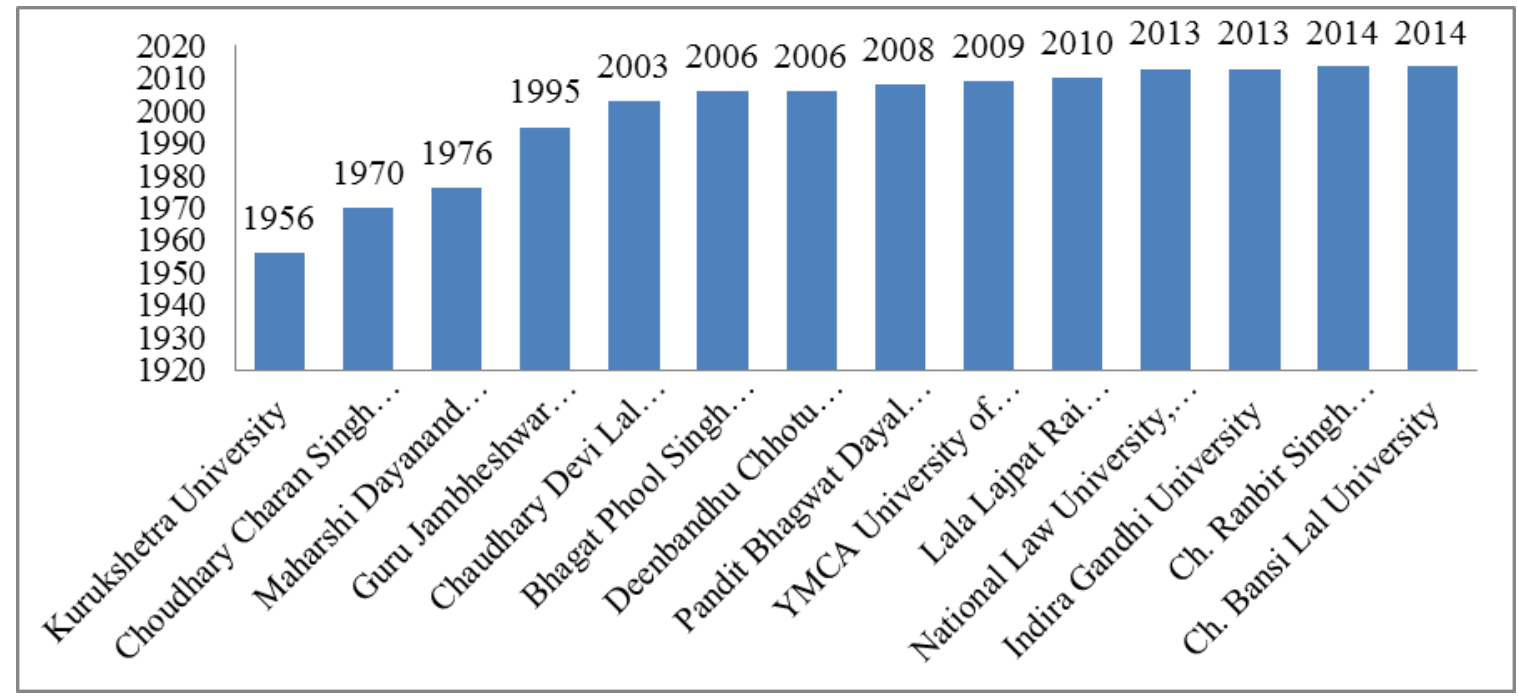

Figure 4. Government Universities in Haryana

The above Figure 3 is also reflecting that there is only one university has been developed in the year 2011 in Kaithal district of Haryana. The maximum strength (Eight) of private Universities is located in Gurgaon district of Haryana. Gurgaon city has seven universities have been developed which is providing higher education to maximum students of NCR region. In the year 2013 and 2012, 2014 there were four, three and three Universities have been created respectively (UGC (2016)).

The government universities constituted under State Legislature Act of Government of Haryana; A Initiation in development of public universities. The UGC has stated that there are fourteen Universities which have been entitled as state government Universities. In the year 2014, only two state Universities have been established in Jind and Bhiwani District. Table 3 is showing the name, city and year of establishment of Government Universities located in Haryana.

Figure 4 shows that government Universities development graph has been moved upward. We can able to see that out of total fourteen Universities; ten Universities have been established after 2000. It is straightforward answer of rapid growth of Higher Education in Haryana. The first University was established in 1956 in district Kurukshetra and then named after Kurkeshta University. After that second was setup in 1970 in Hisar named Choudhary Charan Singh Haryana Agricultural University. In Sirsa District one University has been built in 2003. In 2013, there were two state Universities have been developed named National Law University and Indira Gandhi University in Sonipat and Rewari respectively. The Hisar city has two more Universities such as Guru Jambheshwar University of Science and Technology and Lala Lajpat Rai University of Veterinary and Animal Science founded 
1995 and 2010 respectively. In city Rohtak only one state University named Maharshi Dayanand University

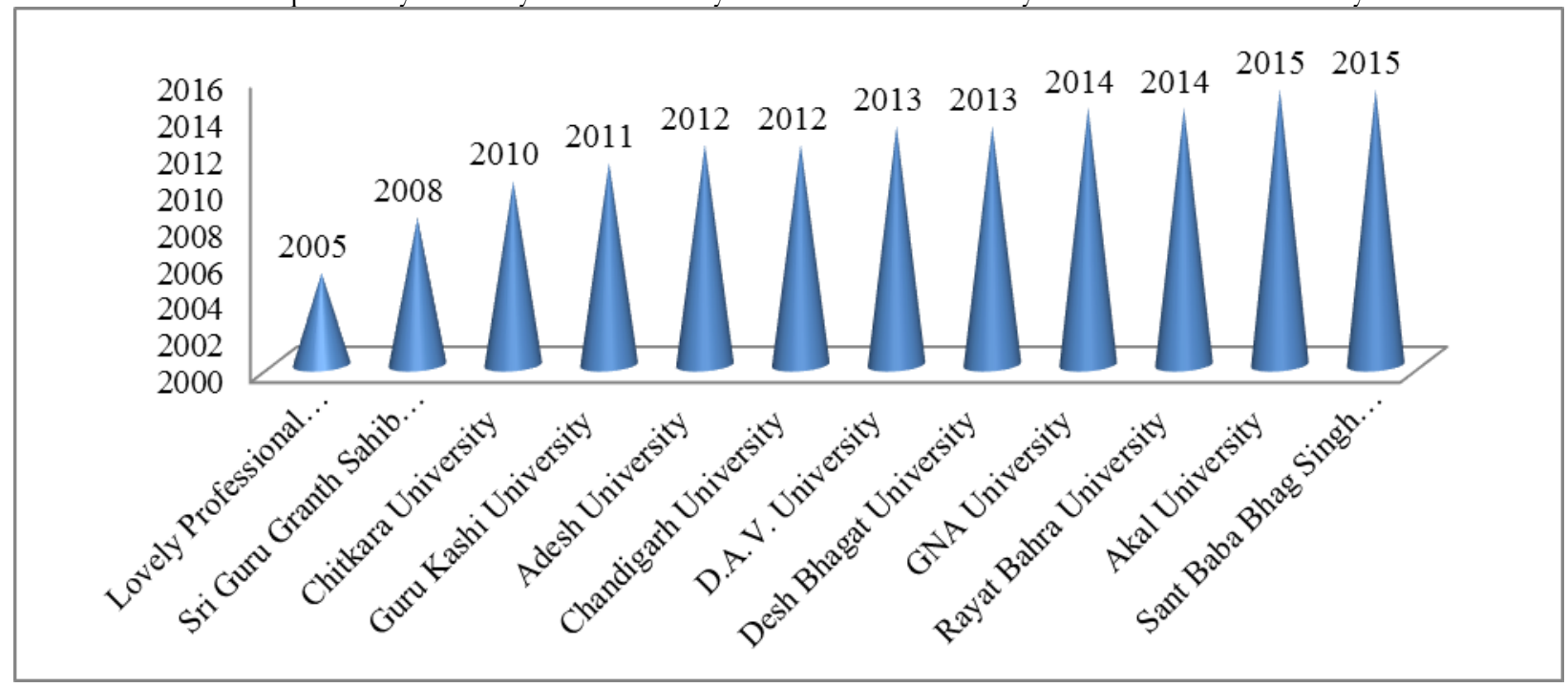

Figure 5. Private Universities in Punjab

founded in 1976. There were only four Universities providing education to students prior to year 2000. It show that even after 50 years of Independency, Government of Haryana was not conscious about Higher education (UGC (2016)).

\section{UNIVERSITIES IN PUNJAB}

After the year 2000, twelve private Universities have been established in Punjab state. Thousands of students are taking higher education in these Universities. Table 5 is reflecting the name of Universities, Year of establishment and city where these are located. There are three Universities in Bathinda; two in Jalandhar, two in Mohali, rest of district have at least one University. The trends of establishment of private Universities have been staring from the year 2000. In the year 2015 and 2014, only two private Universities have been setup respectively. There is no University established before 2005. The growth of University development has been started from 2010.

Figure 5 is showing growth rate of University establishment is increased rapidly after 2000 in Higher education of Punjab state. After the year 2011 the count of University establishment is two in each successive year's up to 2015. The development of the state Government Universities in Punjab state has been increased. Before 2000, only four Government Universities was there in Punjab but now five more Universities has been constituted by state legislature act of Punjab. There is only one University has been developed after the time duration of five year. The Punjab University Chandigarh is the first Government University which has developed in 1956 . The count of University development is five after the year 2000 in Punjab state. Two Universities have located in Ludhiana District of Punjab. Rest of the districts has at least one Government University therein.

Figure 6 reflects the growth rate of Government University establishment has been started from the year 1969. In duration of 1969-2015, only five state Universities have been constituted. Only one University is going to be constructing in time duration of $4-5$ years. The oldest Universities of Punjab are named Punjab University, Punjab Agriculture University, Guru Nanak Dev University situated at Chandigarh, Ludhiana and Amritsar respectively (UGC (2016)).

\section{LIMITATION OF STUDY}

1. This study is confined to Punjab and Haryana states of India only.

2. This study is delimited to private and government universities. 


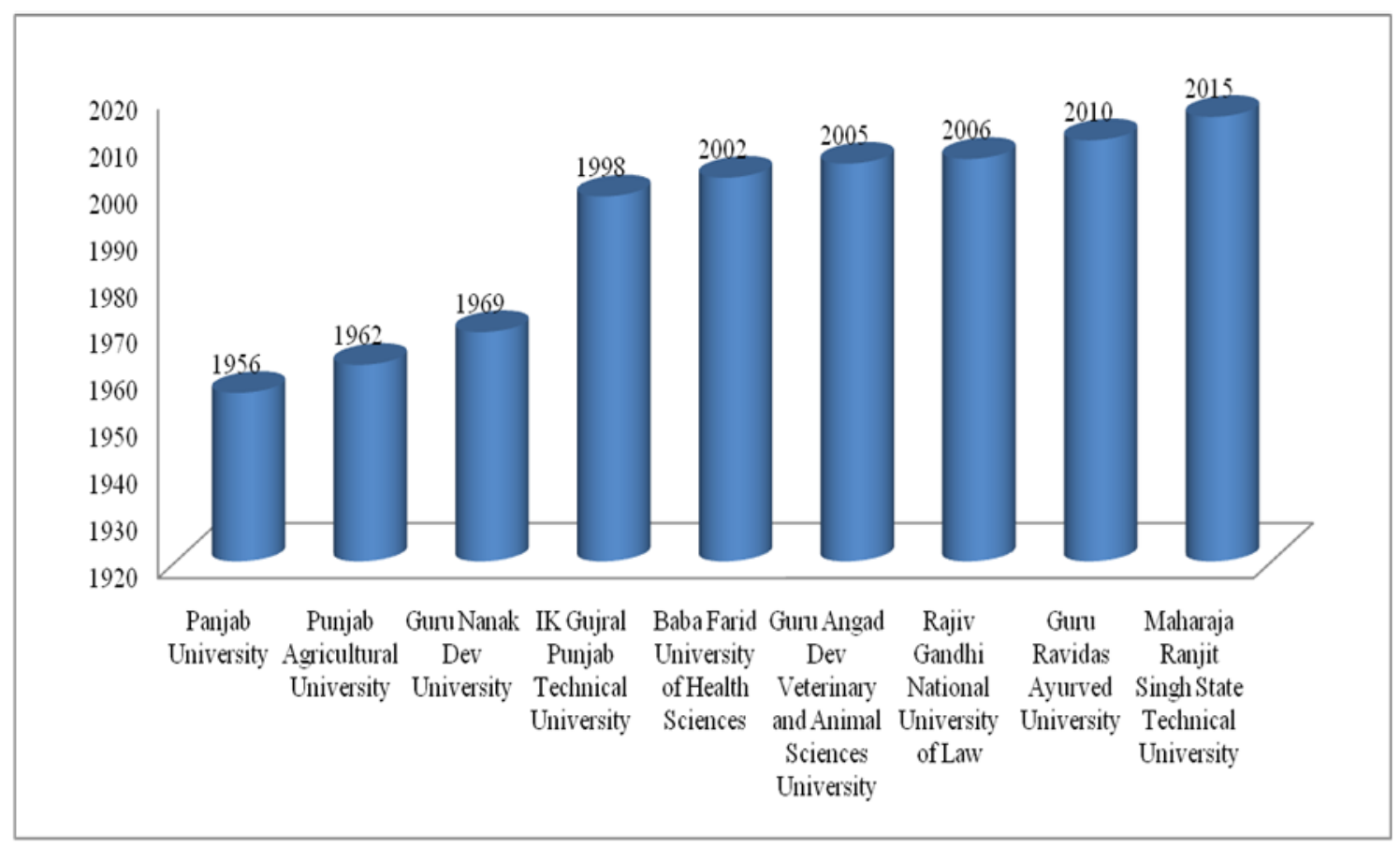

Figure 6. Government Universities in Punjab

\section{CONCLUSION}

This paper reveals that status of higher education was very low before 2000 , as we seen that only few numbers of Universities were established. But after 2000 the strength of higher education get strong and quantity of universities has been increased. This paper also describes that there has been rapid growth of Higher education in Haryana as compare to Punjab. It also reflects that government of states has concentrated on privatization of higher education in these states. The rate of development of private universities is increase swiftly as compare to government universities.

\section{RECOMMENDATIONS}

This study recommends to the government and policy makers of higher education to emphasize on development of government institutions to provide quality education as compare to privatization. There is need to concentrate on quality not on quantity growth of universities in India. Further, it has been suggested to future investigators to examine the status of development of universities / colleges in rest of states in India.

\section{REFERENCES}

UGC: University Grant Commission, (2016), www.ugc.ac.in.

Worldbank: Conference on Governance and Financing of Higher Education, South and East Asia, (2016), http://siteresources.worldbank.org/EDUCATIONLP/Resources/India.pdf 